\title{
The Comparative Study of civil Society Organizations in Combat Corruption in I.R.I and South Korea with Overview to the United Nations Convention against Corruption (UNCAC)
}

\author{
Dr. Abutaleb Motallebi Varkani (Corresponding author) \\ Department of Management, Imam Khomeini Maritime University \\ Nowshahr, Iran \\ Tel: 98-152-332-021Ｅ-mail: abu.m5656@yahoo.com \\ Dr. Amir Nezam Barati \\ Department of Law, Imam Khomeini Maritime University \\ Nowshahr, Iran \\ Tel: 98-115-233-2070Ｅ-mail: nezambarati@gmail.com
}

Received: July 6, 2017 Accepted: August 31, 2017 Published: September 18, 2017

doi:10.5296/jad.v3i2.11882 URL: https://doi.org/10.5296/jad.v3i2.11882

\begin{abstract}
Corruption is a social, political, economic and even security phenomena that defect the democratic institutions and it make a lot of problem for governance (private, civil society and government sectors). Combating corruption is one of the most important factors for establishment of Good Governance. In combat corruption different actor such as government, private sector and civil society have functions, but the role of civil societies are very effective than others.

This study using analytical-descriptive, analyses the role of civil society in combat corruption in I.R. of Iran and South Korea.

Findings of this study shows that in south Korea the role of special civil society organization in combat corruption have remarkable efficiency but in Iran, specialized civil society organizations are in the beginning of the path to tackle corruption or this kind of NGO is not established until now, while the parliament ratified the law of UN Convention against corruption and it is necessary to execute and recognize the role of these NGOs in this hard struggle.
\end{abstract}

Keywords: Civil society, Combat corruption, Iran and South Korea 


\section{Introduction}

One of the most important obstacles of development is corruption. Corruption is a complex phenomenon and It's roots lie deep in bureaucratic and political organizations, and its impact on development change with country conditions (World Bank Group, 2015). Corruption is an abnormality that has a wide range of corrosive effects on societies. It undermines democracy and the rule of law, leads to violations of human rights, distorts markets, wear away the standard of living and allows illegal act, terrorism and other threats to human beings to flourish (Annan, Kofi A., 2003). Corruption Threat the national and international security and increase poverty.

The fight against corruption is inevitable for I.R. of Iran and as follow the order of supreme leader of I.R. of Iran, "The Staff of Challenge Against Economic Corruption [1]" established in Monday, April 30, 2001 (The Staff of Unison Against Economic Corruption, 2015). This staff is a combination of members of 3 branches of powers: the executive; judiciary, and legislature. In I.R of Iran the concentration on fighting against corruption is divided to 3 branches of powers and civil society don't have effective role to fight against this abnormality, but the role of civil society in South Korea are remarkable and effective.

This article seeks to explain how SCSOs [2] can play an important role in combat against financial corruption. In addition we consider the role of SCSOs in I.R. of Iran, South Korea, and answer to the question that how these NGOs can play a similar role in I.R.I. to fight against corruption.

\subsection{Definition and Synopsis's Background of Corruption}

Several definitions of 'corruption' have been proposed within national and international organizations. The abuse of government position for private gain (World Bank Group, 2015) in another definition Corruption is defined as exercise of authorized powers against public interest (Shah, 2006, p. 2). Dishonest or fraudulent behave by those in power, typically involving bribery (Oxford Dictionaries, 2015). In all definition the common subject is break of laws and regulation, dishonest or illegal behavior especially by government officials or police officers. At the end we suggest the definition of corruption as "the abuse of delegated and entrusted power for private gain.

\subsection{Effects and Costs of Corruption on Societies}

According to the International Transparency, Corruption impacts societies in a multitude of ways. This international NGO divided the cost of corruption into four main categories such as political, economic, social and environmental as follow (Transparency International, 2015):

\subsubsection{Political Effects}

On the political effects, corruption is a major obstacle to democracy and the rule of law. In a democratic society, offices and institutions lose their lawfulness when they're abused for private benefit. This abnormal process causing damage in establishing democracy. It is extremely challenging to develop accountability in political system in a corrupt conditions. 


\subsubsection{Economic Effects}

Economically, corruption consume national common wealth. Corrupt politicians invest scarce public resources in projects that will line their pockets rather than benefit societies, and priorities high-profile projects such as dams, power plants, pipelines and refineries over less spectacular but more urgent infrastructure projects such as schools, hospitals and roads. Corruption also prevent the development of fair market structures and deform competition, which in turn discourage investment. According to the assessment of world Bank the international cost of corruption is 1000, 000,000\$ every year (World Bank, 2006, p. 171).

\subsubsection{Social Impacts}

Corruption decreases the social trusts of society. It undermines people's trust to the political system, in its institutions and its leadership. A suspicious and pessimistic of public can be another obstacle to challenging and fight systemic corruption.

\subsubsection{Environmental Effects}

The effect on Environmental degradation is another consequence of corrupt systems. The lack of, or non- execution of, environmental regulations and legislation means that valuable natural resources are exploited carelessly, and entire ecological systems are demolished and corporations across the world continue to offer a bribe in return for unlimited destruction.

\subsection{The Role of Effective Participation of the SCSOs in Fight Against Corruption}

The "SCSOs" has a key role in fighting against corruption, from monitoring public services, condemn bribery to raising consciousness of all economic and political actors. Since most cases of corruption involve public office and private companies, SCSOs as an independent actor representing the interests of the public is exceptionally positioned denounce and disclose corruption cases and put pressure for amendment. Hence Governments, have to take measures to enable and strengthen civil society participation and civil society has to be aware of its role and make use of its potential ability (OECD, Clean Govbiz, 2013, p. 3). An effective and positive participation of the civil society in the battle with corruption depends on some key factors as follows (OECD, Clean Govbiz, 2013, p. 3):

1). The existence of a legal framework that enables SCSOs participation without political and legal restrictions.

2). The willingness of the state to engage constructively with the civil society organization.

3). The effective engagement of CSOs in the fight against corruption.

4). Citizens and CSOs should be aware about the government's anti-corruption action, their role, agenda and actions and the information should be easily accessible especially on the internet and social networks.

5). There should create the infrastructure that Citizens and CSOs should be consulted and actively participating in the decision-making and policy-making processes by government.

6). Citizens should have the right to suggest new legislation and participating in working 
groups for draft the law.

In addition there are two main approaches to fighting corruption: the top-down approach and the bottom-up approach. The top-down approach has to do with developing and naturalizing new rules, institutions, and norms that target the "public administrative graft." Those benefiting from corruption are much less likely to end it than those suffering from corruption, but the importance of the bottom-up approach, which requires the mobilization of ordinary citizens don't need complex starch. A large, united public outcry provides the force of change that reformed infrastructure alone can't (New Tactics, 2010).

From the other viewpoint there are two basic factors that CSOs can do their role to minimize corruption and be fruitful to do this mission:

1)- Freedom of peaceful assembly and of association

2)- Access to information make excellent situation to minimize corruption opinion of government about cooperation with CSOs should be open and fruitful and the government should develop a constructive cooperation with CSOs.

A key part of the process of empowerment is access to information. Citizens who access to information and informed of the corruption within their political systems are able to fight against corruption more effectively as well as develop their own strategies to do so. It is also extremely important to educate people about their rights, especially those who have limited access to such information, such as those living in remoteness and poverty.

Also for effective participation of the SCSOs to fight against corruption we need Active Public participation in the Fight against Corruption (1.3) and Public Scrutiny and access to information (2.3) we discuses about them as follows:

\subsection{The effects of Active Public Participation in the Fight against Corruption}

Active Public participation in the struggle with Corruption is inevitable. The fight against corruption cannot be successful without citizens' support, participation and vigilance of people. The SCSOs play very important role in encouraging public discussion of corruption and increasing awareness about the negative effects of corruption (UNPAN, 2015) .The fight against corruption without the participation of civil society, particularly the special one cannot challenge corruption. The Medias, civil and commercial associations and other NGOs have effective role in forming and exchange the point of view of people and increasing the view point of people to fight against corruption. The experience of developing and developed countries show that recognizing the role of NGOs in combat corruption is one of the most effective toll in combat corruption (hamdami Ghotbeh Saraie, 2008, p. 245). Therefore participation of Special Civil Societies in detection and stoppage of corruption and harmony of the activities of SCS with government are activities that SCS can do to fight against corruption (Secretary-General of the OECD, 2003).

\subsection{Public Inspection and Access to Information}

The CSOs should raising consciousness against corruption and supervising the actions and 
decisions of governments in the areas capable of becoming risk for corruption; they also exposing corruption cases and criticizing corrupt officials and institutions.

CSOs actively promoting civil society's participation and building coalitions with key stakeholders in order to influence the public policy debate and they should be able for lobbying and proposing alternatives for new institutional devices and solutions to prevent or penalize corruption.

In addition one of the key roles of the SCOs in the challenging corruption is to supervise actors and hold them accountable. This inspection is a powerful tools to prevent corruption and a key complement to legal provisions and institutions. Its two preconditions - free discussion and access to related information (ABD/OECD, 2004, p. 36) -, however, are not sufficiently given in some countries like Iran.

The access to information is a tool for power and the access to this power make civil societies to be enabling in supervise the act of government. A particularly important precondition to enabling citizens to inspect the management of public institutions, government, political parties and elected politicians is the real right of access to information. This right goes beyond ordinary publication of documents; additionally effective control requires that governmental or administrative institutions disclose files for inspection when request (ADB/OECD , 2003, p. $37)$.

\section{The Main Causes of Corruption in I.R.I}

The main causes of corruption in I.R. of Iran are Big government, The weakly rule of law, lack of accountability, The inefficient commitment of national administrators, that identified by different studies classified as follow:

\subsection{The Extensive Size and Its Interference of I.R.I of Government}

The extensive size of government and its interference in the economy of the country. These days the role of the state in economy is more than $\% 70$ percent and big industries in I.R. of Iran are governmental. According to the Article 44 of constitutional law of I.R. of Iran the economy of the Islamic Republic of Iran consist of three sectors such as The state, cooperative and private. But the most problem is the extensive size of governmental corporations and their $70 \%$ shares in economy.

\subsection{The Rule of Law is Weakly Embedded}

Public sector corruption flourish where laws enforce to some but not to others, and where enforcement of the law is often used as a device for promotion private interests instead of protecting the community interest (AnwarShah, 2004, p. 43) .according to international transparency the enforcement of the law in I.R of Iran is \%20 in South Korea \%81 and Philippine 35\% (Transparency International, 2010) 
2.3 The Commitment of National Actors to Combat Corruption Is Not Effective and Efficient

Extensive corruption increase and continue in the public sector and governmental organization when three branches of powers are either unwilling or unable to address it powerfully especially when the acts of national leaders to combat corruption is not effective and efficient.

In societies where public sector corruption is indigenous, it is reasonable to suspect that it touches the highest levels of government, and that many senior office holders will not be motivated to work against it. (Anwar Shah and Mark Schacter,, 2004, p. 41)

\subsection{Institutions of Accountability Are Ineffective}

It seems in Iran Institutions of accountability are ineffective and inefficient. These separation of powers don't work very well for example, auditors-general, the judiciary, the legislature or arise outside of formal state structures (for example, the news media and organized civic groups couldn't cooperate and interact with each other. In some cases when civil society activists disclose illegal selling property of Tehran Municipality the judiciary and Tehran Attorney general ordered to arrest the disclosure. There for as Anwar Shah expresed "In societies where public sector corruption is indigenous, it is reasonable to suspect that it touches the highest levels of government, and that many senior office holders will not be motivated to work against it. (Anwar Shah and Mark Schacter,, 2004, p. Ibid).

\section{The Glance of Some National and International Law about the Role of Civil Society against Corruption in Iran}

\subsection{Internal Legislating of I.R. of Iran in Combat Corruption}

\subsubsection{The Law of Supplement of I.R.I. to UN Convention against Corruption}

The supplement of I.R. of Iran to UN Convention against corruption law was ratified by "The Expediency Discernment Council of the System (EDCS)"[3] because of the disagreement between Council Guard and parliament[4] on October 11, 2008 and the legislature recognize the role of civil societies against corruption in article 13 of this law the people's access rights to information and the share of people rights in fighting against corruption was accepted as follows:

"In frame works of I.R.I. law and according to the constitution advisable acts will done for active participation of people and those groups, outside the governments such as civil society, nongovernmental organization and increase the awareness of people for the existence, the reasons, quantity and threat of corruption. The participation of people should increase by access to formation and transparency, participation and accountability. The law of citizen's access to information was ratified by parliament (Majles) in Sunday, January 24, 2010 but the executive bylaw of it was not enacted by the government until 2015 whereas it should prepared by the ministry of culture after 3 month of the time it was passed by The Expediency Discernment Council of the System. This delay show that some part of government disagree with this law and it seems that this kinds of resistance should remove for access of people to information and by rule of law, transparency, accountability and prepare the infrastructure for Performance of this law. 


\subsubsection{The promotion of Purity of Administrative and Collation against Corruption Law}

The "Promotion of Purity of Administrative System and Combat against Corruption law"[5] was passed by "The Expediency Discernment Council of the System (EDCS)" on , October 29, 2011 because of after the ratification of this law by "The Islamic Consultative Assembly or parliament ", was not confirmed by the Council of Guardians, and the Islamic Consultative Assembly (parliament ) insisted on the implementation of the mention law .The article 10 of this law explain that "the interior minister is obliged to develop and empower NGOs to prevent and combat against corruption and Evaluation of corruption index with regarding the Interest of Islamic system according to the law and regulation and present the report of NGOs to parliament", but unfortunately in I.R. of Iran no special NGOs or Civil Society established after 7 years of its ratification and special civil society don't have any role to combat against corruption.

Iran has different law against corruption, such as the Law of Fighting Against Money Laundry, the law of Fighting Against Defalcation, the Law of Prohibition of Government Personnel in Bargains, the Law of Prohibition in Tenure of more than one job in government and the law of Islamic Penalty in Combating Against Corruption... but the main question is why Iran couldn't control or increase the rate of corruption with these widespread laws and its rank is 131 in combating corruption in 2016 ?

\subsubsection{The Role of Civil Societies in UN Convention against Corruption (31 October 2003)}

Postmodern International law is changing concentration from the pedestal state law to human pedestal one. International law is accepting the participation of humankinds and their association in decision making process, Implementation and supervision. Today's the civil society and people try to participate in forming any kind of law ,implementing and supervision on implementation of the law (BaygZadeh, Ebrahim, 2014). The United Nations Convention against Corruption (UNCAC) is a multilateral convention negotiated by members of the United Nations. It is the first global legally binding international anti-corruption instrument that passed of 31 October 2003.

This Convention is the most comprehensive anti-corruption convention, entering into force in December 2005. It covers a wide-range of corruption offences, including domestic and foreign bribery, embezzlement, trading in influence and money laundering. The UNCAC provisions obligate State Parties to take a number of public and private anti-corruption measures (Business-Anti-Corruption Patrol, 2015).

The United Nations Convention against Corruption (UNCAC) recognizes the role of civil society in combating corruption under its Article 13, by "calling on governments to increase transparency, improve public access to information, as well as to promote public contribution to government decision-making processes.

UNODC bolsters the capacity and engagement of civil society, especially from developing countries, by delivering training to CSOs on UNCAC and its review mechanism. UNODC also supports CSO engagement in intergovernmental meetings and provides the necessary tools for 
them to work constructively with their governments and the private sector on UNCAC implementation (OECD, Civil society empowerment, 2013).

This convention in article 13 part " $\mathrm{d}$ " has told that "the freedom may for the protection of national security or public order or of public health or morals. But the question that passes from our mind is how participation of people and civil society in combating corruption can challenge national security, public order of public health or morals while the corruption is dangerous for the mention problem.

\section{The Study of Civil Society Role in Combat Corruption in I.R of Iran, South Korea}

\subsection{Iran}

In spite of the fact that, the combat against corruption is propagated but the special civil societies don't established yet and they don't have any role in fighting against corruption and the only actor is governmental organizations. The formal Statistics show that the vast number of corruption cases shows that corruption is increasing in I.R. I. and combat against corruption is more a election motto (Rabiei, 2012) and civil societies don't have any role in this combat and the most concentration is on government institutes. International Transparency that considered the occurrence of corruption in the world in 2016, classified the score of countries

from zero( high corrupt) to one hundred ( most trans parent).This organization in its report studied 177 countries that shows Corruption Perceptions Index in every part of world. the rank of Iran is 134 from 177 and its score is 27 from 100 . According to the report of this international civil society, Control of Corruption in Iran (2010) is about 20\% (International Transparency, 2015).

In the discussion about Cause Analysis of corruption in Iran we can tell that there is no special academic center to study about corruption. Unlike to the mottos and hubbubs there is no consensus against corruption in the condition that corruption id a social, economical, cultural, political and even security in Iran. There are no formal courses at education centers such as university in the country. There is no remarkable Research about the causes and consequences of corruption and fight against corruption is not scientific and the number of research is not remarkable. The remarkable fact is that the study of cause of corruption is limited by security center of organizations as if corruption is the red line of research and it means that the preparation about the study of the subject is not exist yet. The lack of special civil society as a supervisor in government decision making process is a great weak and there is no sign of it in fight against corruption (Rabiei, 2012).

The most important factor for extension of corruption is governmental economy and big government and until 2015 more than 70\% of Iran economy is governmental and this kind of economy model had not been effective in any part of the world (Eslamian, 2013). The government of Japan with 130 million populations has 339,785 Employee but I.R.I has more than 3488985 in its public and government sectors.

The size of private sector is about $30 \%$ and this process shows that private sector don't have effective role in economy and it cause amplitude or bigness of government is the most 
important reason for financial and political corruption.

\subsection{South Korea}

In South Korea when the civil society started to reform for control of corruption in 1989 the presence of people increased because of the existence of civil societies such as "People's Solidarity for Participatory Democracy (PSPD)" and "Citizens' Coalition for Economic Justice (CCEJ)" and Transparency International (TI)'s national chapter in Korea, as if this country developed interaction with private sectors and civil societies and could receive the rank of 52 in combating against corruption. In this developing country of south East Asia there are different civil societies and non-governmental organization for fighting against corruption. First we consider the Specialized Civil Society Organizations (SCSOs) and the considering their activities as follows:

\subsubsection{The Specialized Civil Society Organizations in Fight against Corruption}

Different Specialized Civil Society Organizations cooperate with the Public Sector in fight against corruption. Civil society organizations have not always combated against the government. They have worked closely with the government when the latter showed their sincere will and invited them to work together. We consider them as follows:

\section{Citizens' Coalition for Economic Justice (CCEJ)}

Before establishing "Citizens' Coalition for Economic Justice (CCEJ)" there were no specialized civil societies organization for combating against corruption that consider the problems of South Korea in corruption. The CCEJ has 35,000 members and 35 local branches, and its work is carried out by about 50 staff nationwide, with the guidance and support of about 150 specialists who serve on the 17 subcommittees of the Policy Research Committee. The subcommittees cover subjects such as Banking, Local Autonomy, Finance and Taxation and Welfare.

Citizens' Coalition for Economic Justice operates the Anti-Corruption Center, which investigates citizens' reports on business and government irregularities and has worked to clean up corruption in the judicial system; (rightlivelihood, 2003)

The characteristics of Citizens' Coalition for Economic Justice (CCEJ) are as follows:

1)-The people run the organization,

2)-Use legal and peaceful method,

3)-Looking for practical and effective replacement,

4)- Defense Interests of people without their financial condition,

5)-Try to establish a participatory society for dominance on greed and egocentric,

\section{People's Solidarity for Participatory Democracy (PSPD)}

PSPD was founded in 1994 by activists, scholars and lawyers who had engaged in various democratic movements during military dictatorship decades. Hoping to open a new era of 
participatory democracy and human rights, PSPD has been working on promoting people's participation in government's decision making process and socio-economic reforms. In 2004, PSPD also obtained a special consultative status with the UN ECOSOC and started to advocate before various UN bodies including the UN Human Rights Council and the Security Council.

\subsubsection{An overview of the activities of SCSOs in South Korea}

Korean Civil society organization has done different activity such as:

1). Creation of Real Name Financial Transaction System1,

2). Freedom of Information Act and Administrative Reforms,

3). Anti-Corruption Law3,

4). Reform of Political Financing,

5). National Budget Monitoring

6). Business Monitoring

7). Call for the indictment of two former corrupt Presidents

8). Negative campaign against corrupt politicians during the 2000 general election.

\section{Result and Design Model for Minimizing Corruption in Developing Countries such as Iran and South Korea}

Different Suggestions such as Service delivery performance, Citizen Empowerment, Dissemination of Information presented for minimizing corruption. one of the most important actions that the I.R.I as developing country should do is economic policy reform and decreases the size and the role of government in economic activity.

In I.R.I the government role in economy is more than $\% 70$ therefore minimizing government role in trade, financial liberalization and real privatization can reduce opportunities for corruption by limiting the situations where officials might exercise unaccountable discretionary powers, introducing transparency and limiting public sector monopoly powers. At the end one of the most important acts for developing country such as Iran is participation specialized civil society in combating corruption.

In I.R.I the only sector that fights against corruption is government. From the establishment of "The Staff of Unison against Economic Corruption" the success was not remarkable and the commitment of governments to fight against corruption is questionable, it is important to engage other national stakeholders such as civil society, people and private sector in fight against corruption is not remarkable. Participatory processes of civil society, people and private sector are very effective method in challenging corruption. In addition Increasing the supervision of civil societies in fight against corruption, developing the disquisition of press to combat corruption and developing the culture of anti-corruption in societies are other factor that are very effective in challenging corruption. At the end I suggest the model for minimizing corruption in developing countries as follows: 


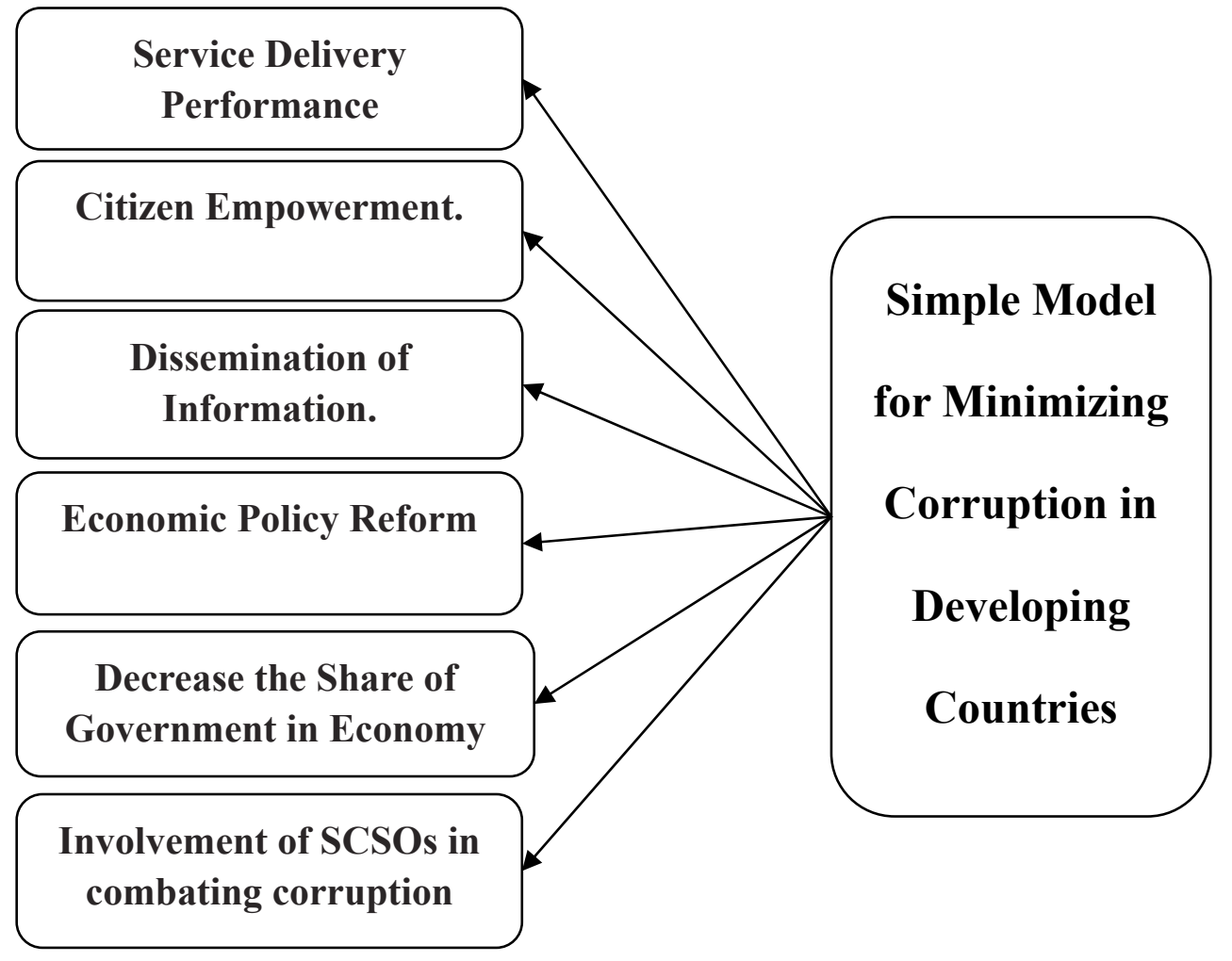

Figure 1. Model for Minimizing Corruption in Developing countries (result of research)

\section{Conclusion}

As noted earlier, in modern world, the scope of economic activity and fiscal Interaction is extensive and complex. Corruption is extensive, social, political, economic and even security phenomenon. Combat against should do by every actor in society. In fight against corruption different actor such as government, private sector, and civil society can ply their role but between mentioned actors, the role of civil society are effective and crucial. Toadies in south Korea Civil Society Organizations such as PSPD, CCEJ are active SCSOs that try to fight against corruption.

In fact in Iran the special civil society are in the begging of their mission and there is no specialized NGO to fight against corruption and governmental organization are the only responsible to combat corruption. It seems that "Iran has long way to participate specialized civil society organizations(SCSOs) against corruption", Iran ranked 131th and South Korea52 out of 176 countries in the 2016 Corruption Perception Index (CPI) of TI, therefore the role of civil societies should be revised.

In fact in Iran there is no special civil society against corruption and the gap are many more than countries such as South Korea, unlike the law that ratified in the parliament of I.R.I and recognition of the role of civil society and recognition of the role of civil society in different law the special civil society don't have considerable role in the battle against corruption. 


\section{Macrothink}

\section{Acknowledgements}

The research is financed by Imam Khomeini Maritime University and directed by Dr. Abutaleb Motallebi Varkani the Manager of Higher Education Department. As colleague I appreciate him. (Dr. Amirnezam Barati)

\section{References}

ABD/OECD. (2004). Anti-Corruption Policies In Asia and Pacific available. OECD Available at,www.oecd.org.

ADB/OECD. (2003). Active Public Involvement ,Public Scrutiny and Access to Information,Anti-Corruption Initiative for Asia and the Pacific. OECD.

Ampratwum, E. F. (2008). The fight against corruption and its implications for development in developing and transition economies. Journal of Money Laundering Control, 11(1), 76-87. https://doi.org/10.1108/13685200810844514

Annan, K. A. (2003). UNITED NATIONS CONVENTION AGAINST CORRUPTION. Retrieved 2015, from https://www.unodc.org/documents/brussels/UN_Convention_Against_ Corruption.pdf.

Annan, K. A. (2003). United Nations Convention against Corruption. New York: https://www.unodc.org/documents/brussels/UN_Convention_Against_Corruption.pdf.

Anwar Shah, S. M. (2004). Combating Corruption: Look Before You Leap, A lack of progress in eradicating corruption could be due to misguided strategies. World Bank, finance and development department.

Anwar, S., \& Mark, S. (2004). Combating Corruption:Look Before You Leap. Finance \& Development, 41.

Bayg Zadeh, E. (2014). the role of civil society in combat against corruption. THE Conference of UN in combat Against Corruption Association for UN Studies (p. http://www.iauns.org/internal_news/detailpage/Fa/). Teheran: Iranian Association for UN Studies .

Burger, E. S. (2006). Why the private sector is likely to lead the next stage in the global fight against corruption.

Business-Anti-Corruption Patrol. (2015). The United Nations Convention against Corruption. Retrieved from http://www.business-anti-corruption.com/about/about-corruption/unitednations-convention-against-corruption.aspx.

Center For The study of Democracy. (2005). Anti corruption Reforms in Bulgaria, civil society against corruption.

Eigen, P. (2002). Measuring and combating corruption. The Journal of Policy Reform (pp. 187-201).

ESCAP, U. (2006). What is good governance?. United Nations. Economic and Social 
Commission for Asia and the. Pacific. available at www.unescap.org.

Eslamian, M. (2013, August 28). the cause of corruption. Retrieved September 2, 2015, from http://iccima.ir/fa/.

Fitzwilliam, E. F. (2008). The fight against corruption and its implications for development in developing and transition economies. Journal of Money Laundering Control, 11(1), 76-87.

Fitzwilliam, E. F. (2011). The fight against corruption and its implications for development in developing and transition economies,. Journal of Money Laundering Control, University of Cambridge, Cambridge, UK, 1.

hamdami Ghotbeh Saraie, A. (2008). Finacial Corruption Cause ,consequence and The Stratgies To Fight Against it. Tehran: Ferdusi Publication.

http://www.unodc.org/unodc/en/corruption/. (210). UNODC's Action against Corruption and Economic Crime.

Huguette, L. (2012). A Speech bout The Role of Civil Society in the Fight Against Corruption. The Role of Civil Society in the Fight Against Corruption. Santo Domingo, Dominican Republic.

International Budget. (2015). Retrieved 5 18, 2015, from http://internationalbudget.org/groups/concerned-citizens-of-abra-for-good-government-ccagg/ International Transparency. (2015). Iran report. Retrieved from http://www.transparency.org/country/\#IRN.

Kim, J., \& Kim, J. (2001). Shareholder Activism in Korea: A Review of How PSPD Has Used Legal Measures to Strengthen Korean Corporate Governancet. Journal of Korean Law, 53.

merriam-webster. (n.d.). corruption. Retrieved june 29, 2016, from merriam-webster: http://www.merriam-webster.com/dictionary/corruption

New Tactics. (2010, August 31). Empowering Citizens to Fight Corruption. Retrieved 6 20, 2015, from https://www.newtactics.org/conversation/empowering-citizens-fight-corruption: https://www.newtactics.org/conversation/empowering-citizens-fight-corruption

OECD, A. (2001). Anti-Corruption Initiative for Asia and the Pacific, Active Public Involvement in the Fight against Corruption. ADB/OECD. ADB/OECD.

OECD,CleanGovbiz. (2013, April). Civil society empowerment. (OECD) Retrieved june 2015, 2017, from OECD: http://www.oecd.org/cleangovbiz/CivilSocietyEmpowermentDraft.pdf

OECD. (2003). Fighting Corruption What Role For Civil Society? The Experience of The OECD. Paris : OECD.

OECD. (2013 ). available at www.cleangovbiz.org. 
OECD. (2013, April ). Civil society empowerment. Retrieved August 11, 2015, from http://www.oecd.org/cleangovbiz/CivilSocietyEmpowermentDraft.pdf.

Oxford Dictionaries. (2015). Retrieved from http://www.oxforddictionaries.com/definition/english/corruption.

Pacific, U. N. (2014). Accountability cannot be enforced without transparency and the rule of law. Retrieved from www.unescap.org/pdd

Rabiei, A. (2012). Interview about sociology of corruption (M. a. Behzad, Interviewer)

rightlivelihood. (2003). Citizens' Coalition for Economic Justice, CCEJ (2003, South Korea). Retrieved 5 10, 2015, from http://www.rightlivelihood.org/ccej.html.

Robert, K., \& Heather, B. (1997). Working together to fight corruption: state, society and the private sector in partnership. In T. Suzanne, \& L., Jose Edgardo, Governance Innovations: Lessons from Experience, Building Government-Citizen-Business Partnerships.

Secretary-General of theOECD. (2003). Fighting Corruption What Role For Civil Society? The Experience of The OECD. OECD.

Shah, A. (2006). Corruption and Decentralized Public Governance. World Bank Policy Research Working Paper, NO. 3824. Retrieved from https://openknowledge.worldbank.org/handle/10986/8805.

Shah, A. A. (2004). Combating corruption: look before you leap. Finance and Development, $41(4), 40-43$.

The central Staff of Challenge Against Economic Corruption. (2015). Economic Corruption. Retrieved 5 25, 2015, from http://ww.nezarat.gov.ir/.

The Staff of Unison Against Economic Corruption. (2015). Economic Corruption. Retrieved 5 25, 2015, from nezarat: http://ww.nezarat.gov.ir/

Transparency International. (2010). Corruption by Country / Territory. Retrieved 2015, from Transparency International: https://www.transparency.org/country/\#PHL

Transparency International. (2015). WHAT ARE THE COSTS OF CORRUPTION. Retrieved July 27, 2016, from International: http://www.transparency.org/what-is-corruption/\#costs-of-corruption

UNODC. (2014). UNODC's Action against Corruption and Economic Crime. Retrieved from http://www.unodc.org/unodc/en/corruption/

UNODC. (2104). United Nations Economic and Social Commission, What is Good Governance?,. available at www.unescap.org.

UNPAN. (2015). Active Public Involvement in the Fight against Corruption. Retrieved from http://unpan1.un.org/intradoc/groups/public/documents/apcity/unpan021383.pdf.

Vinay, B., \& Emil, B. (2004). Challenging Corruption in Asia. Washington, D.C.: The World 
$\mathrm{Ba}$. 2017, Vol. 3, No. 2

VitoTanzi, H. D. (1997). Corruption, Public Investment, and Growth. IMF Working Paper97/139, p. 4.

Wikileaks. (2015). Concerned Citizens of Abra for Good Government (CCAGG). Retrieved 8 25, 2015, from https://wikileaks.org/wiki/Concerned_Citizens_of_Abra_for_Good_ Government_\%28CCAGG\%29.

World Bank Group. (2015). Helping Countries Combat Corruption: The Role of the World $\begin{array}{lllll}\text { Bank. } & \text { Retrieved } & 6 & 17, & 2015,\end{array}$ http://www1.worldbank.org/publicsector/anticorrupt/corruptn/cor02.htm.

World Bank Group. (2015). Helping Countries Combat Corruption: The Role of the World Bank. Retrieved 6 17, 2015, from worldbank: http://www1.worldbank.org/publicsector/anticorrupt/corruptn/cor02.htm

World Bank. (2014). Helping Countries Combat Corruption: The Role of the World Bank. http://www1.worldbank.org/publicsector/anticorrupt/corruptn/corrptn.pdf.

WorldBank. (2006). report. Oxford University Press: WorldBank.

You, J. (2003). The Role of Civil Society in Combating Corruption in Korea. 11th International Anti-Corruption Conference (pp. 1-11). Seoul, Korea.

Zibakalam, S. (2015, May 28). the cause of corruption is dominance of government in economy. Retrieved July 4, 2015, from https://www.tabnak.ir/fa/news/504073.

\section{Copyright Disclaimer}

Copyright for this article is retained by the author(s), with first publication rights granted to the journal.

This is an open-access article distributed under the terms and conditions of the Creative Commons Attribution license (http://creativecommons.org/licenses/by/4.0/). 